\title{
Effects of inorganic nitrogen forms on growth, morphology, nitrogen uptake capacity and nutrient allocation of four tropical aquatic macrophytes (Salvinia cucullata, Ipomoea aquatica, Cyperus involucratus and Vetiveria zizanioides)
}

\author{
Arunothai Jampeetong $^{\mathrm{a}, *}{\text {, Hans } \text { Brix }^{\mathrm{b}} \text {, Suwasa Kantawanichkul }}^{\mathrm{c}}$ \\ a Department of Biology, Faculty of Science, Chiang Mai University, Meuang, Chiang Mai 50202, Thailand \\ ${ }^{\mathrm{b}}$ Department of Bioscience, Plant Biology, Aarhus University, Ole Worms Alle 1, 8000 Aarhus C, Denmark

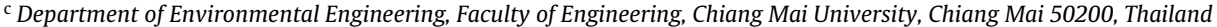

\section{A R T I C L E I N F O}

\section{Article history:}

Received 18 January 2011

Received in revised form

28 September 2011

Accepted 17 October 2011

Available online 29 October 2011

\section{Keywords:}

Ammonium uptake

Constructed wetland

Nitrate uptake

Umbrella sedge

Vetiver grass

Water spinach

\begin{abstract}
A B S T R A C T
This study assesses the growth and morphological responses, nitrogen uptake and nutrient allocation in four aquatic macrophytes when supplied with different inorganic nitrogen treatments (1) $\mathrm{NH}_{4}{ }^{+}$, (2) $\mathrm{NO}_{3}{ }^{-}$, or (3) both $\mathrm{NH}_{4}{ }^{+}$and $\mathrm{NO}_{3}{ }^{-}$. Two free-floating species (Salvinia cucullata Roxb. ex Bory and Ipomoea aquatica Forssk.) and two emergent species (Cyperus involucratus Rottb. and Vetiveria zizanioides (L.) Nash ex Small) were grown with these $\mathrm{N}$ treatments at equimolar concentrations $(500 \mu \mathrm{M})$. Overall, the plants responded well to $\mathrm{NH}_{4}{ }^{+}$. Growth as RGR was highest in S. cucullata $\left(0.12 \pm 0.003 \mathrm{~d}^{-1}\right)$ followed by I. aquatica $\left(0.035 \pm 0.002 \mathrm{~d}^{-1}\right)$, C. involucratus $\left(0.03 \pm 0.002 \mathrm{~d}^{-1}\right)$ and $V$. zizanioides $\left(0.02 \pm 0.003 \mathrm{~d}^{-1}\right)$. The $\mathrm{NH}_{4}{ }^{+}$uptake rate was significantly higher than the $\mathrm{NO}_{3}{ }^{-}$uptake rate. The free-floating species had higher nitrogen uptake rates than the emergent species. The $\mathrm{N}$-uptake rate differed between plant species and seemed to be correlated to growth rate. All species had a high $\mathrm{NO}_{3}{ }^{-}$uptake rate when supplied with only $\mathrm{NO}_{3}{ }^{-}$. It seems that the $\mathrm{NO}_{3}{ }^{-}$transporters in the plasma membrane of the root cells and nitrate reductase activity were induced by external $\mathrm{NO}_{3}{ }^{-}$. Tissue mineral contents varied with species and tissue, but differences between treatments were generally small. We conclude, that the free-floating $S$. cucullata and $I$. aquatica are good candidate species for use in constructed wetland systems to remove $\mathrm{N}$ from polluted water. The rooted emergent plants can be used in subsurface flow constructed wetland systems as they grow well on any form of nitrogen and as they can develop a deep and dense root system.
\end{abstract}

(c) 2011 Elsevier B.V. All rights reserved.

\section{Introduction}

The capacity of aquatic macrophytes to remove and assimilate excess nutrients in constructed wetlands (CWs) has resulted in the use of CWs for treating a variety of wastewater types. Ammonium $\left(\mathrm{NH}_{4}{ }^{+}\right)$and nitrate $\left(\mathrm{NO}_{3}{ }^{-}\right)$are major forms of inorganic nitrogen found in wastewater runoff from households and farmlands that degrade the water quality. Plants have an important role in CWs for removing nutrients. The ability to take up nitrogen, a vital nutrient for plant growth, is different among plant species. Free-floating macrophytes directly obtain nitrogen and other nutrients from the water column through their roots. Many species of these plants such as Eichhornia crassipes (Mart.) Solms, Pistia stratiotes L., Lemna spp., Salvinia spp., etc. have been used in free water surface systems. In contrast, subsurface flow system and vertical flow system are dominated by emergent macrophytes, which obtain nutrients

\footnotetext{
* Corresponding author. Tel.: +66 53943346 51; fax: +66 53892259.

E-mail address: ajampeetong@yahoo.com (A. Jampeetong).
}

from the substrate via roots (Brix and Schierup, 1989; Ran et al. 2004; Iamchaturapatr et al., 2007; Kantawanichkul et al., 2009).

Plant selection for water treatment is an important component of CW system design, especially selecting suitable plants for different types of wastewater. Various nitrogen forms have different effects on growth and nitrogen uptake of plants. Several studies have shown that aquatic macrophytes grow well when $\mathrm{NH}_{4}{ }^{+}$is the main nitrogen source probably because less energy is needed for $\mathrm{NH}_{4}{ }^{+}$uptake and assimilation compared to $\mathrm{NO}_{3}{ }^{-}$nutrition (Room and Thomas, 1986; Petrucio and Esteves, 2000; Fang et al., 2007; Jampeetong and Brix, 2009a; Konnerup and Brix, 2010). Despite the fact that many tropical plants have been used in water treatment systems (Boonsong and Chansiri, 2008; Kantawanichkul et al., 2009; Konnerup et al., 2009), their nitrogen nutrition is not well understood.

Salvinia cucullata Roxb. ex Bory and Ipomoea aquatica Forssk are tropical free-floating macrophytes. Many species of Salvinia have a high growth rate and high dispersal rate and have consequently been spreading around the world. A study by Jampeetong and Brix (2009a) showed that S. natans has a higher growth rate 
when supplied with $\mathrm{NH}_{4}{ }^{+}$than when supplied with $\mathrm{NO}_{3}{ }^{-}$, and the species tolerates $\mathrm{NH}_{4}{ }^{+}$concentration up to at least $5 \mathrm{mM}$, which is approximately the level commonly found in domestic wastewater (Jampeetong and Brix, 2009b). Similarly, I. aquatica grows in water bodies with high $\mathrm{N}$ and $\mathrm{P}$ concentrations, and can remove nutrients and some heavy metals from polluted waters (Göthberg et al., 2002; Lin et al., 2002; Li et al., 2007; Weerasinghe et al., 2008). Moreover, this species is an edible plant with a high protein content that can be used as animal fodder (Somkol, 2009). However, the responses of S. cucullata and I. aquatica to various forms of N are unknown. Emergent macrophytes like Cyperus involucratus Rottb. and Vetiveria zizanioides (L.) Nash ex Small have been used in tropical CWs (Kantawanichkul et al., 2009; Xiao et al., 2009). C. involucratus is a common plant in eutrophic tropical wetlands. $V$. zizanioides is widely used to reduce soil erosion and in water treatment systems in Southeast Asia, because of its high tolerance to diverse growth conditions and the fact that it can be harvested and used for many proposes. However, information concerning nitrogen uptake and mineral allocation of these species is limited.

Here, we assess the growth and morphological responses of four tropical aquatic macrophytes to different forms of inorganic nitrogen. We also evaluate nitrogen uptake and nutrient allocation in the plant tissue when the plants are supplied with $\mathrm{NH}_{4}{ }^{+}, \mathrm{NO}_{3}{ }^{-}$, and combined $\mathrm{NH}_{4} \mathrm{NO}_{3}$ treatment.

\section{Materials and methods}

\subsection{Plant materials and growth conditions}

Plants with similar weights and/or height (depending on the species), S. cucullata Roxb. ex Bory, I. aquatica Forssk., C. involucratus Rottb. and V. zizanioides (L.) Nash ex Small, were selected and cultivated in hydroponic culture in the greenhouse at the Department of Biology, Faculty of Science, Chiang Mai University, Thailand at a temperature range of $32-35^{\circ} \mathrm{C}$ during the day and $22-25^{\circ} \mathrm{C}$ at night. The light regime was approximately $80 \%$ of full sun and the light:dark cycle was 14:10 h. The growth medium was a half-strength standard nitrogen-free nutrient solution (Smart and Barko, 1985) to which a commercial micronutrient solution for aquarium plants (Tropica Master Grow, Tropica Aquacare, Aarhus, Denmark) was added. The composition of the solution was $(\mu \mathrm{M})$ : $\mathrm{K}^{+} 21, \mathrm{Mg}^{2+} 16.7, \mathrm{~S}^{2-} 32.8, \mathrm{~B}^{3+} 0.4, \mathrm{Cu}^{2+} 0.1, \mathrm{Fe}^{2+} 1.3, \mathrm{Mn}^{2+} 0.8$, Mo 0.02 and $\mathrm{Zn}^{2+}$ 0.03. Phosphorus was added as $\mathrm{KH}_{2} \mathrm{PO}_{4}(100 \mu \mathrm{M})$. The $\mathrm{pH}$ of the growth medium was adjusted to 7.0.

Nitrogen was supplied as $\mathrm{NH}_{4}{ }^{+}$and/or $\mathrm{NO}_{3}{ }^{-}$in equimolar concentrations $(500 \mu \mathrm{M})$ to create the following three treatments: (i) $500 \mu \mathrm{M} \mathrm{NH}_{4}{ }^{+}$(ii) $500 \mu \mathrm{M} \mathrm{NO}_{3}{ }^{-}$, and (iii) $250 \mu \mathrm{M} \mathrm{NH} \mathrm{NO}_{3}$. Ten replicates of $I$. aquatica, $C$. involucratus and $V$. zizanioides and five replicates of $S$. cucullata were used for each treatment. The initial fresh weights (FW) of all experimental plants were measured and the fresh and dry weights (DW) of ten uniform sized plants were measured to estimate DW to FW ratio. Clonal fragments from S. cucullata stock cultures (approximately $2 \mathrm{~g} \mathrm{FW}$ ) and I. aquatica (approximately $10 \mathrm{~g} \mathrm{FW}$ and $30 \mathrm{~cm}$ tall) were placed in $5 \mathrm{~L}$ containers. C. involucratus (approximately $7 \mathrm{~g}$ FW and $15 \mathrm{~cm}$ tall) and $V$. zizanioides (approximately $6 \mathrm{~g} \mathrm{FW}$ and $20 \mathrm{~cm}$ tall) were placed in $1 \mathrm{~L}$ containers. All treatments were arranged in a randomized complete block design in the greenhouse. The growth medium was replaced every two days to avoid depletion of nutrients.

\subsection{Growth study}

All plants were harvested, cleaned, and their morphological characteristics recorded after four weeks for $I$. aquatica and $S$. cucullata and six weeks for $C$. involucratus and V. zizanioides when plants were fully acclimated to the growth conditions. The individual plants were separated into shoots and roots, freeze dried and weighed. The relative growth rate $\left(\mathrm{d}^{-1}\right)$ for each treatment was calculated using the formula: $\mathrm{RGR}=\left(\ln W_{2}-\ln W_{1}\right) /\left(t_{2}-t_{1}\right)$, where $W_{1}$ and $W_{2}$ are the initial and final DW, and $t_{1}$ and $t_{2}$ are initial and final time (days).

\section{3. $N$ uptake rate}

After the growth experiment, the $\mathrm{NO}_{3}{ }^{-}$and $\mathrm{NH}_{4}{ }^{+}$uptake rates of the acclimated plants were determined. Plants of uniform size $(n=4)$ from each treatment were pre-incubated for $18 \mathrm{~h}$ in a container with a $\mathrm{N}$-free growth medium under the same conditions as the growth study. After pre-incubation, I. aquatica, C. involucratus, and $V$. zizanioides were placed in $240 \mathrm{~mL}$ vessels with $500 \mu \mathrm{M} \mathrm{NO}_{3}{ }^{-}$ or $\mathrm{NH}_{4}{ }^{+}$, S. cucullata was placed in a $300 \mathrm{~mL}$ beakers. $\mathrm{NO}_{3}{ }^{-}$and $\mathrm{NH}_{4}{ }^{+}$uptake was estimated based on $\mathrm{N}$ depletion (Konnerup and Brix, 2010). The $\mathrm{NH}_{4}{ }^{+}$concentration in all samples was analysed using a modified salicylate method (Quikchem Method no. 10107-06-3-B; Lachat Instruments, Milwaukee, WI, USA). The $\mathrm{NO}_{3}{ }^{-}$ concentration was analysed from the absorbance at $202 \mathrm{~nm}$ and $250 \mathrm{~nm}$ (Cedergreen and Madsen, 2003). After the uptake experiment $(6 \mathrm{~h})$, all plants were separated into shoots and roots, freeze dried and weighed. The $\mathrm{N}$ uptake rate was calculated from the depletion curves with linear regression analyses and related to root DW.

\subsection{Chlorophyll content}

The contents of Chl $a$, Chl $b$ and total Chl $a+b$ in the leaves of each plants were analysed according to Lichtenthaler (1987). Freeze dried leaves from each plant were cut into small pieces and weighed into 5-10 mg samples. Pigments were extracted with $8 \mathrm{~mL}$ of $96 \%$ ethanol in the dark at room temperature. After $24 \mathrm{~h}$, the absorbance of the extracts was measured at $648.6 \mathrm{~nm}$ and $664.2 \mathrm{~nm}$ using a UV-vis spectrophotometer (Lambda 25 version 2.85.04, USA).

\subsection{Mineral elements}

The concentration of total N, phosphorus (P), potassium (K), calcium (Ca) and magnesium $(\mathrm{Mg})$ in the plant tissue was analysed in subsamples (150-180 mg) of finely ground freeze dried plant material. The samples were digested by mixing with $7 \mathrm{~mL}$ of an acid solution (concentrate $\mathrm{H}_{2} \mathrm{SO}_{4} 1 \mathrm{~L}, \mathrm{~K}_{2} \mathrm{SO}_{4} 100 \mathrm{~g}$ and selenium $1 \mathrm{~g}$ ) at a temperature range of $100-330^{\circ} \mathrm{C}$. Total $\mathrm{N}$ was analysed by the Kjeldahl method (Hanlon et al., 1994) and the concentrations of P, K, Ca and Mg were analysed according to Chapman and Pratt (1978).

\subsection{Statistics}

All statistics were carried out using Statgraphics Plus ver. 4.1 (Manugistics, Inc., MD, USA). Data were tested for normal distribution and homogeneity of variance using Cochran's C-test. If necessary, data were log-transformed to ensure homogeneity of variance. The data was tested by both one-way and two-way analysis of variance (ANOVA). Differences between treatments were identified by the Tukey HSD's test at a 5\% significance level.

\section{Results}

\subsection{Growth study}

The relative growth rate (RGR) of plants varied between species and was affected by $\mathrm{N}$-source (Fig. $1 \mathrm{a}$, Table 1 ). S. cucullata had a relative growth rate $\left(0.12 \pm 0.003 \mathrm{~d}^{-1}\right)$ that was substantially higher than the three other species. Increase in RGR was found in both $C$. 

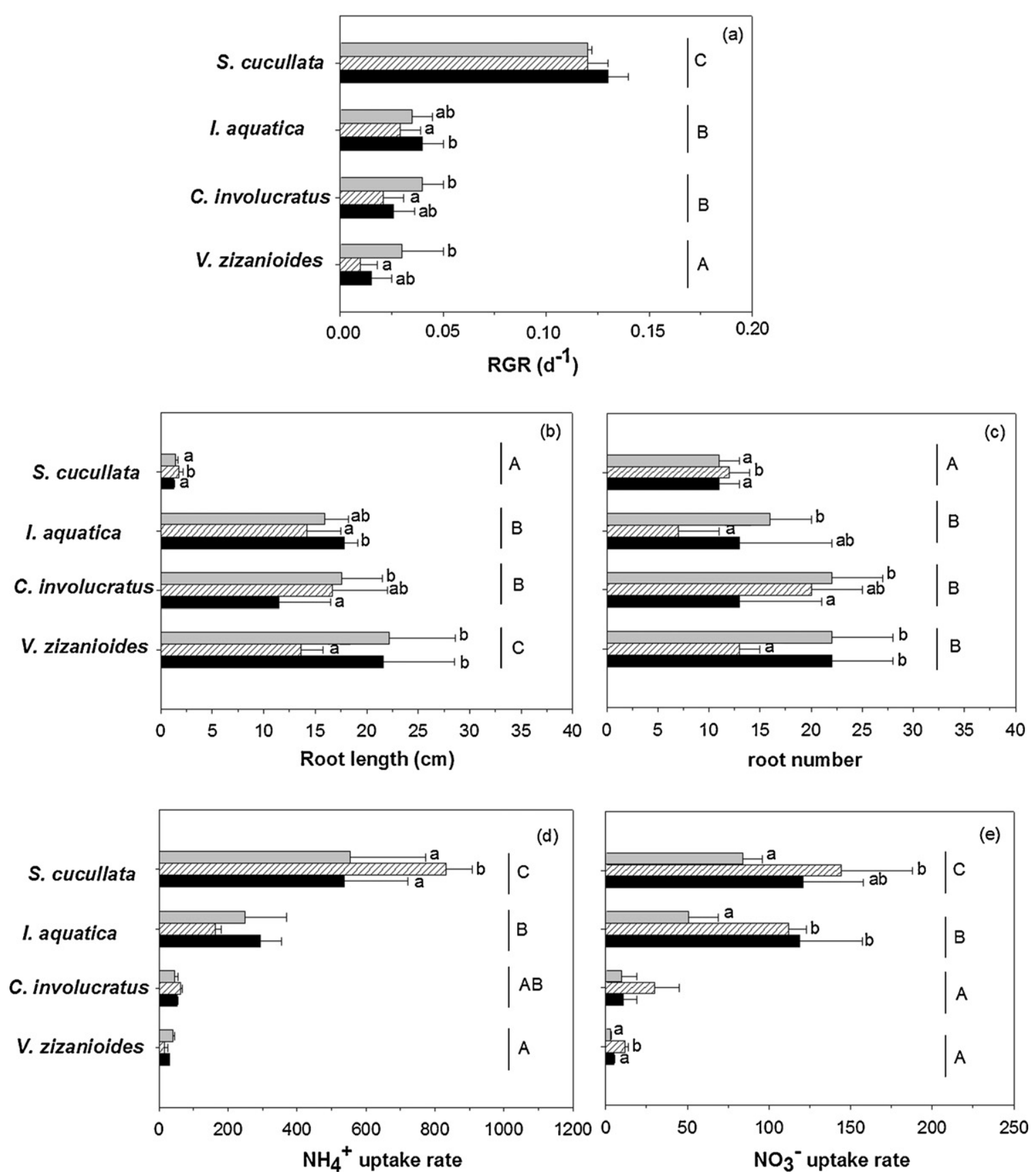

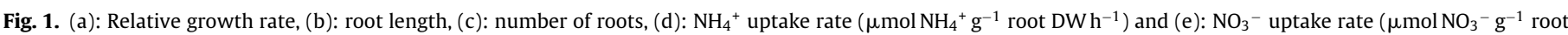

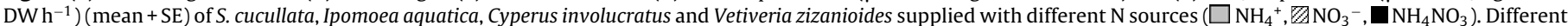

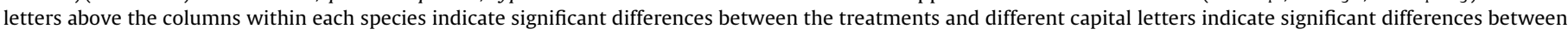
the plant species.

involucratus and $V$. zizanioides when supplied with $\mathrm{NH}_{4}{ }^{+}$(Fig. 1a). There were $43 \%$ and $82 \%$ increases in the RGRs of $\mathrm{NH}_{4}{ }^{+}$fed plants compared to $\mathrm{NO}_{3}{ }^{-}$fed plants in $C$. involucratus and $V$. zizanioides, respectively.

\subsection{Morphological characteristics}

Both root length and root number was affected by plant species and $\mathrm{N}$ source and a significant interaction was observed (Table 1 , Fig. $1 \mathrm{~b}$ and $\mathrm{c}$ ). The longest roots were found in $V$. zizanioides, followed by C. involucratus, I. aquatica and S. cucullata, (Fig. 1b). New shoot production was different among plant species and was independent of $\mathrm{N}$ source. I. aquatica and C. involucratus produced new shoots faster than $V$. zizanioides.

\subsection{Chlorophyll content}

Plant species and N source interactively affected Chl $a, \mathrm{Chl} b$ and total Chl $a+b$ (Table 1). Average chlorophyll content was highest in I. aquatica, followed by S. cucullata, C. involucratus and V. zizanioides (Table 2). The chlorophyll contents of $\mathrm{NH}_{4}{ }^{+}$fed plants were consistently higher than that of $\mathrm{NO}_{3}{ }^{-}$fed plants, except for I. aquatica where the chlorophyll contents were highest in the $\mathrm{NH}_{4} \mathrm{NO}_{3}$ treatment. 
Table 1

Results of a two-way ANOVA (F-ratios) of growth, morphological characteristics, chlorophyll concentrations, $\mathrm{N}$-uptake rate and mineral concentrations of Salvinia cucullata, Ipomoea aquatica, Cyperus involucratus and Vetiveria zizanioides grown with different $\mathrm{N}$-sources $\left(500 \mu \mathrm{M} \mathrm{NH}_{4}{ }^{+}, 500 \mu \mathrm{M} \mathrm{NO}_{3}{ }^{-}\right.$and $\left.250 \mu \mathrm{M} \mathrm{NH}_{4} \mathrm{NO}_{3}\right)$.

\begin{tabular}{|c|c|c|c|}
\hline & \multicolumn{2}{|l|}{ Main effect } & \multirow{2}{*}{$\begin{array}{l}\text { Interaction } \\
\text { Plant } \\
\text { species } \times \mathrm{N} \text {-source }\end{array}$} \\
\hline & Plant species & N-source & \\
\hline $\operatorname{RGR}\left(\mathrm{d}^{-1}\right)$ & $311.8^{* * *}$ & 0.85 & 1.42 \\
\hline Root number & $14.4^{* * *}$ & $3.22^{*}$ & $2.42^{*}$ \\
\hline Root length $(\mathrm{cm})$ & $68.0^{* * *}$ & 2.5 & $3.25^{* *}$ \\
\hline New shoots & $80.6^{* * *}$ & 0.5 & 1.45 \\
\hline $\begin{array}{l}\mathrm{NH}_{4}^{+} \text {uptake rate } \\
\left(\mu \mathrm{mol} \mathrm{NH}_{4}^{+} \mathrm{g}^{-1} \text { root } \mathrm{DWh}^{-1}\right) \\
\mathrm{NO}_{3}{ }^{-} \text {uptake rate }\end{array}$ & $114.0^{* * *}$ & $2.89^{*}$ & $3.17^{*}$ \\
\hline$\left(\mu \mathrm{mol} \mathrm{NO}{ }_{3}^{-} \mathrm{g}^{-1}\right.$ root $\left.\mathrm{DWh}^{-1}\right)$ & $55.8^{* * *}$ & $8.92^{* * *}$ & $2.43^{*}$ \\
\hline Chl $a\left(\mathrm{mg} \mathrm{g}^{-1} \mathrm{DW}\right)$ & $27.3^{* * *}$ & 3.10 & $5.61^{*}$ \\
\hline Chl $b\left(\mathrm{mg} \mathrm{g}^{-1} \mathrm{DW}\right)$ & $47.2^{* * *}$ & $3.86^{*}$ & $4.04 *$ \\
\hline Total Chl $a+b\left(\mathrm{mg} \mathrm{g}^{-1} \mathrm{DW}\right)$ & $34.4^{* * *}$ & $3.43^{*}$ & $5.09^{* * *}$ \\
\hline Chl $a /$ Chl $b$ ratio & 2.53 & 0.74 & $5.30^{* * *}$ \\
\hline \multicolumn{4}{|l|}{ Total $\mathrm{N}\left(\mathrm{mg} \mathrm{g}^{-1} \mathrm{DW}\right)$} \\
\hline leaves & $30.2^{* * *}$ & 0.51 & 0.62 \\
\hline roots & $49.3^{* * *}$ & 1.81 & 0.36 \\
\hline \multicolumn{4}{|l|}{$\mathrm{P}\left(\mathrm{mg} \mathrm{g}^{-1} \mathrm{DW}\right)$} \\
\hline leaves & $207.8^{* * *}$ & 1.05 & $2.66^{*}$ \\
\hline roots & $33.8^{* * *}$ & 1.42 & 1.61 \\
\hline \multicolumn{4}{|l|}{$\mathrm{K}\left(\mathrm{mg} \mathrm{g}^{-1} \mathrm{DW}\right)$} \\
\hline leaves & $22.4^{* * *}$ & 0.38 & 0.83 \\
\hline roots & $173.8^{* * *}$ & $6.63^{* *}$ & $4.70^{* *}$ \\
\hline \multicolumn{4}{|l|}{$\mathrm{Ca}\left(\mathrm{mg} \mathrm{g}^{-1} \mathrm{DW}\right)$} \\
\hline leaves & $78.4^{* * *}$ & 1.09 & $4.05^{* *}$ \\
\hline roots & $38.0^{* * *}$ & 0.35 & 1.64 \\
\hline \multicolumn{4}{|l|}{$\operatorname{Mg}\left(\mathrm{mg} \mathrm{g}^{-1} \mathrm{DW}\right)$} \\
\hline leaves & $117.8^{* * *}$ & $2.80^{*}$ & $11.57^{* * *}$ \\
\hline roots & $16.1^{* * *}$ & 1.63 & 0.49 \\
\hline
\end{tabular}

${ }^{*}, P<0.05 ;{ }^{* *}, P<0.01 ;{ }^{* * *}, P<0.001$.

\subsection{N-uptake}

Nitrogen uptake differed among plant species, but all species had higher uptake rates for $\mathrm{NH}_{4}{ }^{+}$than for $\mathrm{NO}_{3}{ }^{-}$(Fig. 1d and e). S. cucullata had significantly higher uptake rates for both $\mathrm{NH}_{4}{ }^{+}$ and $\mathrm{NO}_{3}{ }^{-}$than the other species. $\mathrm{NO}_{3}{ }^{-}$uptake was affected by both plant species and $\mathrm{N}$-source and a significant interaction was observed in the ANOVA (Table 1 ). For all species, $\mathrm{NO}_{3}{ }^{-}$uptake rate was high in plants supplied with $\mathrm{NO}_{3}{ }^{-}$either alone or in combination with $\mathrm{NH}_{4}{ }^{+}$.

\subsection{Nutrient and mineral elements}

The concentration of most nutrient and mineral elements (N, P, $\mathrm{Ca}, \mathrm{K}, \mathrm{Mg}$ ) in both leaves and roots differed among the four species (Fig. 2). The concentration of $\mathrm{N}$ and $\mathrm{P}$ in leaves and $\mathrm{K}$ in roots was significantly affected by plant species and N-source and a significant interaction was observed in the ANOVA (Table 1). The lowest nutrient and mineral contents in leaves and roots were generally found in $V$.zizanioides. The $\mathrm{N}$ concentration was consistently higher in leaves than in roots. In S. cucullata, the $\mathrm{N}$ concentration in leaves was significantly higher in the $\mathrm{NH}_{4}{ }^{+}$and $\mathrm{NH}_{4} \mathrm{NO}_{3}$ fed plants than in the $\mathrm{NO}_{3}{ }^{-}$fed plants. The P concentration in the leaves of $S$. cucullata was significantly lower in the $\mathrm{NO}_{3}{ }^{-}$fed plants than in the $\mathrm{NH}_{4}{ }^{+}$fed plants. In the roots of $C$. involucratus, the $P$ concentration was significantly higher in the $\mathrm{NO}_{3}{ }^{-}$fed plants than the other treatments. The other mineral cations were only slightly affected by $\mathrm{N}$ sources in all four species. In $\mathrm{NO}_{3}{ }^{-}$fed C. involucratus, $\mathrm{Mg}$ concentration in leaves was high, and in leaves of $\mathrm{NO}_{3}{ }^{-}$fed $V$. zizanioides Ca concentration was high. $\mathrm{NH}_{4}{ }^{+}$fed plants of I. aquatica had significantly higher concentrations of $\mathrm{Ca}$ in leaves than plants fed with either $\mathrm{NO}_{3}{ }^{-}$or $\mathrm{NH}_{4} \mathrm{NO}_{3}$.

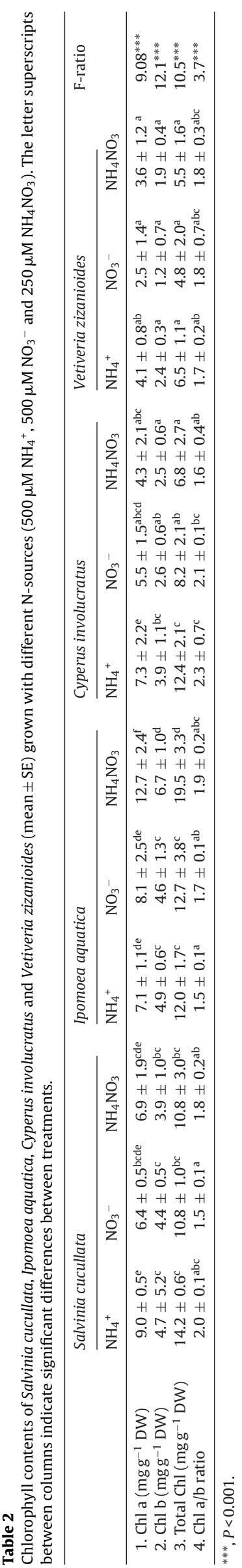



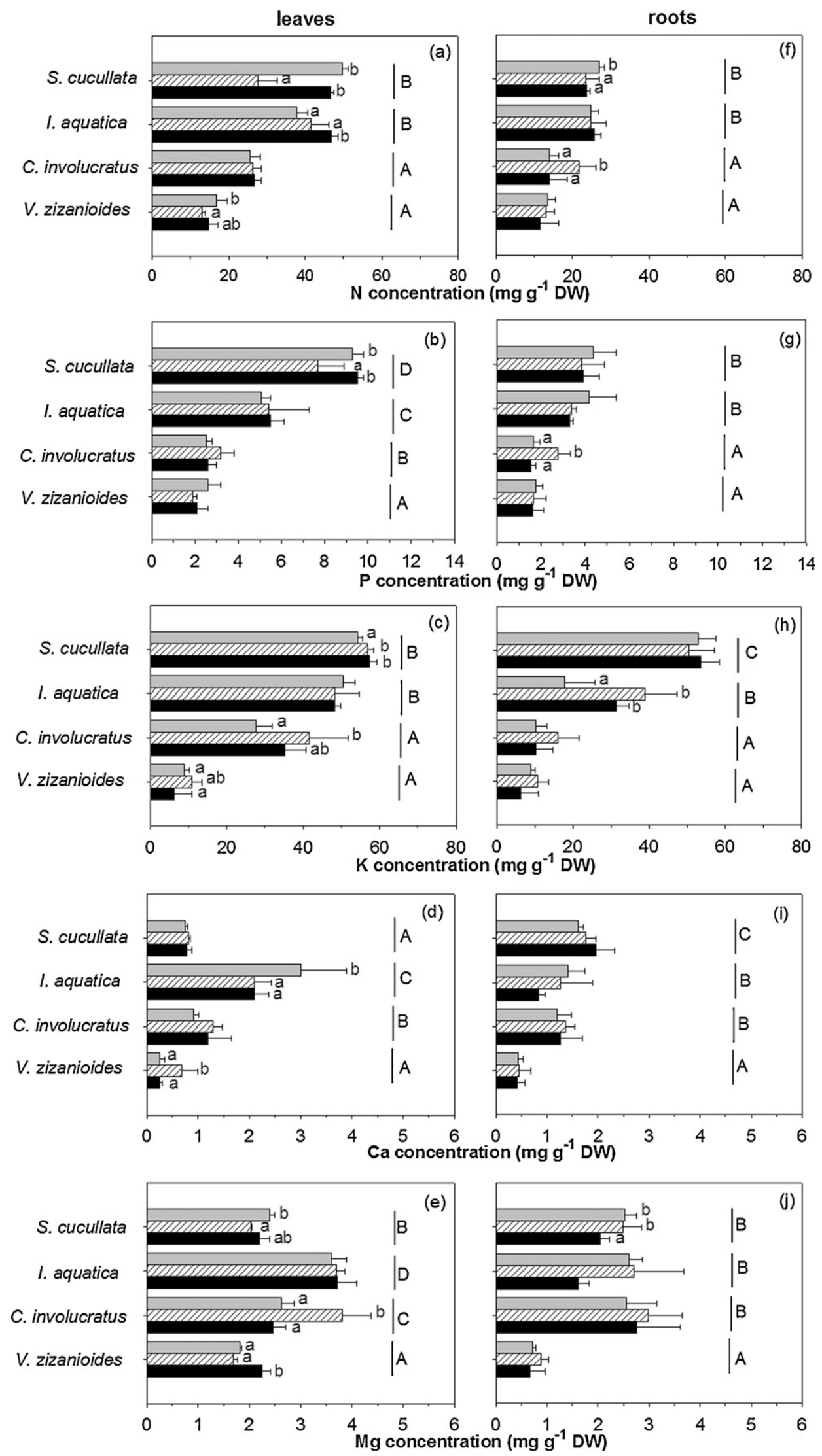

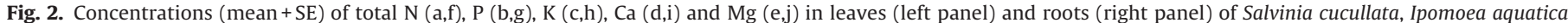


indicate significant differences between the treatments and different capital letters indicate significant differences between the plant species. 


\section{Discussion}

The relative growth rates (RGR) of the free-floating plants were higher than the RGRs of the emergent plants. Free-floating plants obtain nutrients from the water column through root uptake and through the underside of their leaves (Cedergreen and Madsen, 2002; Fang et al., 2007). In the present study most mature leaves of $S$. cucullata were in poor contact with the water as the leaves were raised up above the water surface. Hence, nutrient uptake via leaves was probably insignificant compared to root absorption. Generally, Salvinia species grow rapidly and form dense mats with doubling times of two to four days over still waters (McFarland et al., 2004). S. cucullata had RGRs ranging from 0.12 to $0.13 \mathrm{~d}^{-1}$ in the present study, and the growth rate was unaffected by the $\mathrm{N}$ source. This is in contrast to previous studies on $S$. natans and S. molesta which had a higher growth rate when grown on $\mathrm{NH}_{4}{ }^{+}$ than on $\mathrm{NO}_{3}{ }^{-}$(Jampeetong and Brix, 2009a; McFarland et al., 2004). Many species of aquatic macrophytes prefers $\mathrm{NH}_{4}{ }^{+}$over $\mathrm{NO}_{3}{ }^{-}$as a $\mathrm{N}$-source, possibly because of the lower energy needed for its uptake and assimilation, and because of the prevalence of $\mathrm{NH}_{4}-\mathrm{N}$ in water-saturated anoxic soils (Miller and Cramer, 2005; Fang et al., 2007; Jampeetong and Brix, 2009a; Konnerup and Brix, 2010). The study of Sorrell and Orr (1993) showed that C. involucratus had a high net $\mathrm{H}^{+}$extrusion and a high $\mathrm{N}$-uptake rate when $\mathrm{NH}_{4}{ }^{+}$was the nitrogen source. Others have reported similar findings for other wetland plants including Carex rostrata Stokes, Typha latifolia L. and Phragmites australis Cav (Trin) ex Steudel (Conlin and Crowder, 1989). In the present study, particularly C. involucratus and V. zizanioides grew better on $\mathrm{NH}_{4}{ }^{+}$than on $\mathrm{NO}_{3}{ }^{-}$, as has also been found for Glyceria maxima (Hartm.) Holmb (Tylova-Munzarova et al., 2005). $V$. zizanioides had a deep root system with dense lateral roots, but a low growth rate and low $\mathrm{N}$-uptake rate compared to the other species in this study. Thus, $V$. zizanioides seems to less suitable for removal of $\mathrm{N}$ in wastewater treatment systems.

The free-floating plants had higher $\mathrm{N}$-uptake rates than the emergent plants. The $\mathrm{N}$-uptake rate seems to be correlated to the growth rate and hence the $\mathrm{N}$ demand. S. cucullata had high growth rates and correspondingly high uptake rate for both $\mathrm{NH}_{4}{ }^{+}$and $\mathrm{NO}_{3}{ }^{-}$. The average $\mathrm{NH}_{4}{ }^{+}$uptake rate was $640 \pm 161 \mu \mathrm{mol} \mathrm{g}-1$ root $\mathrm{DWh}^{-1}$ and was similar to published values of $679 \pm 97 \mu \mathrm{mol} \mathrm{g}^{-1}$ root $\mathrm{DWh}^{-1}$ for Salvinia natans (Jampeetong and Brix, 2009a). The $\mathrm{N}$ uptake rates of the emergent plants were lower, but the plants had either more roots or greater root length than the free-floating plants. New roots and root laterals are the principal site of nutrient uptake because old roots may develop thick epidermal and hypodermal lignification and suberization that impede nutrient uptake (Sorrell et al., 1993). Hence, a large fraction of the root system of the emergent plants may not have been involved in the $\mathrm{N}$ uptake, and uptake rates in the new active roots may have been at a similar level as the uptake by $S$. cucullata roots which are not much lignified (Jampeetong and Brix, 2009c).

As also reported in other studies, the studied species significantly increased $\mathrm{NO}_{3}{ }^{-}$uptake rate when external $\mathrm{NO}_{3}{ }^{-}$was present (Crawford et al., 1986; Gojon et al., 1994; Cedergreen and Madsen, 2002; Jampeetong and Brix, 2009a; Konnerup and Brix, 2010). Nitrate transporters in the root plasma membranes and nitrate reductase activity (NRA) are generally induced by external $\mathrm{NO}_{3}{ }^{-}$availability. Most free floating species have high NRA in roots (Cedergreen and Madsen, 2003), whereas rooted emergent species usually have higher NRA in leaves than in the roots (Munzarova et al., 2006). Nitrate reduction and assimilation in leaves seem to be an advantage as the ATP needed for reduction can be coupled to the photophosphorylation in the chloroplasts. Konnerup and Brix (2010) found that the $\mathrm{NO}_{3}{ }^{-}$uptake by Canna indica L., which had high NRA in the leaves, was not affected by the type of N-source. This corresponds to the observations in the present study.
Nitrogen nutrition have been reported to affect the concentrations of cations in the plant tissues with lower concentrations in $\mathrm{NH}_{4}{ }^{+}$fed plants than $\mathrm{NO}_{3}{ }^{-}$fed plants (Tylova-Munzarova et al., 2005; Jampeetong and Brix, 2009a; Dan and Brix, 2009). In the present study, the N-source only slightly affected mineral concentration in the plant tissues of the studied plant species. Other studies have reported similar findings for $C$. indica and Sesbania sesban (L.) Merr. which only responded with small changes in tissue mineral concentration when supplied with different forms of N (Dan and Brix, 2009; Konnerup and Brix, 2010).

We conclude, that the free-floating macophytes $S$. cucullata and I. aquatica are good candidate species for use in constructed wetland systems to remove $\mathrm{N}$ from domestic or agricultural wastewater because of their high growth rates and high $\mathrm{N}$ uptake capacity. Furthermore, their high mineral and protein contents as well as the ease of harvesting makes these species promising for use as feed crops for animals and/or soil fertilizers (Leterme et al., 2009; Somkol, 2009). The rooted emergent plants can be used in subsurface flow constructed wetland systems as they grow well on any form of nitrogen and as they can develop a deep and dense root system.

\section{Acknowledgements}

The study was funded by The Thailand Research Fund and Commission on Higher Education, Project No. MRG5280224 and supported by the Danish Council for Independent Research-Natural Sciences.

\section{References}

Boonsong, K., Chansiri, M., 2008. Domestic wastewater treatment using vetiver grass cultivated with floating platform technique. Assumption University: J. Technol. $12,73-80$.

Brix, H., Schierup, H.-H., 1989. The use of aquatic macrophytes in water-pollution control. AMBIO 18, 100-107.

Cedergreen, N., Madsen, T.V., 2002. Nitrogen uptake by the floating macrophyte Lemna minor. New Phytol. 155, 285-292.

Cedergreen, N., Madsen, T.V., 2003. Nitrate reductase activity in roots and shoots of aquatic macrophytes. Aquat. Bot. 76, 203-212.

Chapman, H.D., Pratt, P.F., 1978. Methods of Analysis for Soils, Plants and Waters. Division of Agricultural Sciences, University of California, U.S.A.

Conlin, T.S.S., Crowder, A.A., 1989. Location of radial oxygen loss and zones of potential iron uptake in a grass and two nongrass emergenr species. Canadian J. Bot. 67, 717-722.

Crawford, N.M., Campbell, W.H., Davis, R.W., 1986. Nitrate reductase from squashcDNA cloning and nitrate regulation. Proc. Natl. Acad. Sci. U.S.A. 83, 8073-8076.

Dan, T.H., Brix, H., 2009. Growth responses of the perennial legume Sesbania sesban to $\mathrm{NH}_{4}{ }^{+}$and $\mathrm{NO}_{3}{ }^{-}$nutrition and effects on root nodulation. Aquat. Bot. 91, 238-244.

Fang, Y.Y., Babourina, O., Rengel, Z., Yang, X.E., Pu, P.M., 2007. Ammonium and nitrate uptake by the floating plant Landoltia punctata. Ann. Bot. 99, 365-370.

Gojon, A., Plassard, C., Bussi, C., 1994. Root/shoot distribution of $\mathrm{NO}_{3}-$ assimilation in herbaceous and woody species. In: Roy, J., Garnier, E. (Eds.), A Whole Plant Perspective on Carbon-Nitrogen Interactions. SPB Academic Publishing, Hague, pp. 131-148.

Göthberg, A., Greger, M., Bengtsson, B.-E., 2002. Accumulation of heavy metals in water spinach (Ipomoea aquatica) cultivated in the Bangkok region. Thailand Environ. Toxicol. Chem. 21, 1934-1939.

Hanlon, E.A., Gonzales, J.G., Bartos, J.M., 1994. Soil testing laboratory chemical procedures and training manual. Circular 812, Institute Food and agricultural Science, University of Florida, Gainesville, FL.

Iamchaturapatr, J., Yi, S., Rhee, J., 2007. Nutrient removals by 21 aquatic plants for vertical free surface-flow (VFS) constructed wetland. Ecol. Eng. 29, 287-293.

Jampeetong, A., Brix, H., 2009a. Nitrogen nutrition of Salvinia natans: effect of inorganic nitrogen form on growth, morphology, nitrate reductase activity and uptake kinetics of ammonium and nitrate. Aquat. Bot. 90, 67-73.

Jampeetong, A., Brix, H., 2009b. Effects of $\mathrm{NH}_{4}{ }^{+}$concentration on growth, morphology and $\mathrm{NH}_{4}^{+}$uptake kinetics of Salvinia natans. Ecol. Eng. 35, 695-702.

Jampeetong, A., Brix, H., 2009c. Oxygen stress in Salvinia natans: interactive effects of oxygen availability and nitrogen source. Environ. Exp. Bot. 66, 153-159.

Kantawanichkul, S., Kladprasert, S., Brix, H., 2009. Treatment of high-strength wastewater in tropical vertical flow constructed wetlands planted with Typha angustifolia and Cyperus involucratus. Ecol. Eng. 35, 238-247.

Konnerup, D., Brix, H., 2010. Nitrogen nutrition of Canna indica: effects of ammonium versus nitrate on growth, biomass allocation, photosynthesis, nitrate reductase activity and $\mathrm{N}$ uptake rates. Aquat. Bot. 92, 142-148. 
Konnerup, D., Koottatep, T., Brix, H., 2009. Treatment of domestic wastewater in tropical, subsurface flow constructed wetlands planted with Canna and Heliconia. Ecol. Eng. 35, 248-257.

Leterme, et al., 2009. Nutritional value of aquatic ferns (Azolla filiculoides Lam. and Salvinia molesta Mitchell) in pigs. Anim. Feed Sci. Technol. 149, 135-148.

Li, M., Wu, Y.-J., Yu, Z.-L., Sheng, G.-P., Yu, H.-Q., 2007. Nitrogen removal from eutrophic water by floating-bed-grown water spinach (Ipomoea aquatica Forsk.) with ion implantation. Water Res. 41, 3152-3158.

Lichtenthaler, H.K., 1987. Chlorophylls and carotenoids: pigments of photosynthetic biomembranes. Methods Enzymol. 148, 350-382.

Lin, Y.F., Jing, S.R., Lee, D.Y., Wang, T.W., 2002. Nutrient removal from aquaculture wastewater using a constructed wetlands system. Aquaculture 209, 169-184.

McFarland, D.G., Nelson, L.S., Grodowitz, M.J., Smart, R.M., Owens, C.S., 2004. Salvinia molesta D.S. Mitchell (Giant Salvinia) in the United States: A review of species ecology and approaches to management. In: Environmental Laboratory ERDC/EL SR-04-2. US Army Corps of Engineer, Engineer Research and Development Center, Washington, D.C, pp. 1-33.

Miller, A., Cramer, M., 2005. Root nitrogen acquisition and assimilation. Plant Soil $274,1-36$, Germany.

Munzarova, E., Lorenzen, B., Brix, H., Vojtiskova, L., Votrubova, O., 2006. Effect of $\mathrm{NH}_{4}{ }^{+} / \mathrm{NO}_{3}{ }^{-}$availability on nitrate reductase activity and nitrogen accumulation in wetland helophytes Phragmites australis and Glyceria maxima. Environ. Exp. Bot. 55, 49-60.

Petrucio, M.M., Esteves, F.A., 2000. Influence of photoperiod on the uptake of nitrogen and phosphorus in the water by Eichhornia crassipes and Salvinia auriculata. Rev. Bras. Biol. 60, 373-379.
Ran, N., Agami, M., Oron, G., 2004. A pilot study of constructed wetlands using duchweed (Lemna gibba L.) for treatment of domestic primary effluent in Israel. Water Res. 38, 2241-2248.

Room, P.M., Thomas, P.A., 1986. Nitrogen, phosphorus and potassium in Salvinia molesta Mitchell in the field: effects of weather, insect damage, fertilizers and age. Aquat. Bot. 24, 213-232.

Smart, R.M., Barko, J.W., 1985. Laboratory culture of submerged freshwater macrophytes on natural sediments. Aquat. Bot. 21, 251-263.

Somkol, P., 2009. Water spinach (Ipomoea aquatica) as a feed resource for growing rabbits. Revista Computadorizada de Produccion Porcina 16, 91-99.

Sorrell, B.K., Orr, P.T., 1993. $\mathrm{H}^{+}$uptake and nutrient uptake by roots of emergent hydrophytes, Cyperus involucratus Rottb., Eleocharis sphacelata R. Br. and Juncus ingens N.A. Wakef. New Phytol. 125, 85-92.

Sorrell, B.K., Brix, H., Orr, P.T., 1993. Oxygen exchange by entire root systems of Cyperus invulocratus and Eleocharis sphacelata. J. Aquat. Plant Manage. 31 24-28.

Tylova-Munzarova, E., Lorenzen, B., Brix, H., Votrubova, O., 2005. The effects of $\mathrm{NH}_{4}{ }^{+}$ and $\mathrm{NO}_{3}{ }^{-}$on growth resource allocation and nitrogen uptake kinetics of Phragmites australis and Glyceria maxima. Aquat. Bot. 81, 326-342.

Weerasinghe, A., Ariyawnasa, S., Weerasooriya, R., 2008. Phyto-remediation potential of Ipomoea aquatica for $\operatorname{Cr}(\mathrm{VI})$ mitigation. Chemosphere 70 , 521-524.

Xiao, W., Bao-ping, H., Ying-zheng, S., Zong-qiang, P., 2009. Advanced wastewater treatment by integrated vertical flow constructed wetland with Vetiveria zizanioides in north China. Procedia Earth Planet. Sci. 1, 1258-1262. 